\title{
Erratum to: On the equivalence of Kalman filtering and least-squares estimation
}

\author{
E. Mysen $^{1}$
}

Published online: 28 February 2017

(C) Springer-Verlag Berlin Heidelberg 2017

\section{Erratum to: J Geod (2017) 91:41-52 \\ DOI 10.1007/s00190-016-0936-3}

As requested by the Springer Quality Assurance Team, I point out that the DOI of reference Glaser et al. (2015) is wrong in the article Mysen (2017). The correct DOI is $10.1007 /$ s00190-015-0842-0.

\section{References}

Glaser S, Fritsche M, Sośnica K, Rodríguez-Solano CJ, Wang K, Dach R, Hugentobler U, Rothacher M, Dietrich R (2015) A consistent combination of GNSS and SLR with minimum constraints. J Geod 89:1165-1180. doi:10.1007/s00190-015-0842-0

Mysen E (2017) On the equivalence of Kalman filtering and leastsquares estimation. J Geod 91:41-52

The online version of the original article can be found under doi:10.1007/s00190-016-0936-3.

\footnotetext{
E. Mysen

eirik.mysen@kartverket.no

1 Geodetic Institute, Norwegian Mapping Authority (NMA), 3507 Hønefoss, Norway
} 